\title{
Stefan Auer
}

\section{The Paradoxes of the Revolutions of 1989 in}

Central Europe'

ABSTRACT

The self-limiting revolutions of 1989 in Central Europe offer an alternative paradigm of revolutionary change that is reminiscent more of the American struggle for independence in 1776 than the Jacobin tendencies that grew out of the French Revolution of 1789. In order to understand the contradictory impulses of the revolutions of 1989- the desire for a radical renewal and the concern for preservation-this article takes as its point of departure the political thought of $\mathrm{Hannah}$ Arendt and Edmund Burke.

KEYWORDS: Arendt, Burke, collapse of communism, Conservatism, Jacobinism, self-limiting revolution, 1989

This article seeks to unravel the paradoxes of the revolutions of 1989 in Central Europe ${ }^{2}$ by taking seriously the ideas and ideals that guided the dissident intellectuals in their struggle for liberty and the rule of law. They were driven by the desire not to repeat the mistakes of the revolutionary regime that they fought against—communism—and imposed limits on both their methods and goals. The result was a self-limiting revolution that resembled more the American struggle for independence in 1776 than the French Revolution of 1789 . Hence, 1989 offers a radically different paradigm of revolutionary change that is reminiscent of certain aspects of thinking of Hannah Arendt and Edmund Burke. Both authors dealt, from their vastly different vantage points, with the challenges of modernity. Arendt's work that highlighted the virtues of the American Revolution in contrast to the shortcomings of its French counterpart is particularly relevant to a better understanding of 1989.3 Similarly, Burke's thoughts on the French Revolution are remarkably prescient to the problems that the leaders of the revolutions in Central Europe had to face two centuries later: what is an adequate response to the challenge of radical revolutionary ideologies (from Jacobinism in the eighteenth century to Marxism-Leninism in the twentieth century)?

A reappraisal of 1989 should help us in addressing one of the fundamental questions of modern political life: How to build lasting political structures on the basis of a revolution? One possible answer is simply to avoid having a revolution. Or, if you absolutely must have a revolution (because, for example, there is no other way of ending a tyrannical regime) it is best to pretend that what is happening is not really a revolution. As a revolutionary leader, do so as if you were neither a revolutionary, nor a leader (as Václav Havel did in December 1989). The end-result may be strange and self-contradictory-a 'conservative revolution' - but it is one that creates possibilities for the establishment of lasting political institutions that preserve liberty under the rule of law. This is one of the reasons why Edmund Burke would have been likely to endorse the self-limiting revolutions of 1989, even though he vehemently opposed their famous predecessor, the French Revolution of 1789. In 1989, in contrast to 1789 , a new beginning was presented as a 'return to normality', and a radical social and political change was implemented by strikingly moderate methods.

Hence, I will argue that the events of 1989 are best understood as self-limiting conservative revolutions in the Burkean sense. This concept is clearly based on an oxymoron: one cannot be both a conservative and a revolutionary. One cannot aim at a radical political change while, at the same time, be willing to accept the constraints of traditions and (to some extent at least) the existing political realities of the day. Yet, the aim of this article is not to resolve these inconsistencies, but rather to identify the conflicting imperatives, which endowed the events of 1989 in Central Europe with their unique 
character. Similarly, no sensible political actor can hope to eliminate all contradictions from political life. In fact, the relative success of reluctant revolutionaries may have been partly due to their realisations of their own limits. ${ }^{4}$ This realisation was reflected in the employed strategies: the concept of selflimiting revolutions; the ideal of 'anti-politics' and of an ethical civil society; and the idea of combining the pursuit of ambitious future oriented goals with a reverence to (some aspects of) the past.

A precautionary note is in order here: clearly, a number of substantive conservative ideals cherished by Burke towards the end of the eighteenth century have lost their relevance today. It is the spirit of Burke's thinking (or the Great Melody in Conor Cruise O'Brien terminology) $)^{5}$ rather than just his particular statements and positions that I believe are useful for an analysis of the 1989 revolutions. As Martin Krygier has suggested, one should differentiate between "methodological conservatism [that] is compatible with a variety of substantive political commitments" and "normative conservatism" that is based on "a positive evaluation and attachment to what exists." ${ }^{\prime 6}$ This distinction makes it possible to characterise the leading dissidents in Central Europe as reluctant, or even 'conservative revolutionaries'. Even though people like Václav Havel, György Konrád and Adam Michnik ${ }^{7}$ differed a great deal amongst themselves, and in relation to Burke, with respect to their substantive political commitments, they shared "a distinctive view of the methods appropriate to politics." ${ }^{\prime 8}$ In line with this, I would see the militant counter-revolutionary pose that Burke adopted towards the end of his life as a betrayal of one of his guiding principles: the idea that dogmatic ideological thinking had to be rejected in any form. At any rate, the term conservative employed in this article is not to be confused with a dogmatic position based on a set of doctrines that amount to conservative ideology. The rejection of Jacobinism must go hand in hand with the rejection of ideologies. Hence, the dilemma that Burke and his followers had to confront was how to fight against Jacobinism without resorting to the very same Jacobin tendencies they opposed. ${ }^{9}$

Thus, it would be a very simplistic, though not an entirely implausible reading of Burke, to construe the 1989 revolutions in Central Europe as 'counterrevolutions'. Burke's Reflections on the Revolution in France was seen as "the manifesto of a counter-revolution" as early as $1791 .{ }^{10}$ It can be argued that Burke's criticism of the destructive tendencies in the French Revolution was even more applicable to Marxism and the series of communist revolutions, which started with the October Revolution in 1917. ${ }^{11}$ Hence, the defeat of communism in 1989 could be simply seen as amounting to the unmaking of 1917. In line with this, the controversial German historian, Ernst Nolte, interpreted the 1989 revolutions as attempts to negate the destruction of 1917 (which brought about the total destruction of bourgeoisie) by the 'restoration' of liberal democracy. Not surprisingly, Nolte also reads these events as the final confirmation of his 'grand theory' of twentieth century history. 1989 marks the end of the 'Weltbürgerkrieg', that is the world civil war-the term Nolte coined for the description of the cold war. World civil war was, according to Nolte, the logical continuation of the European civil war 1917-1945, which was characterised by the violent struggle of two competing ideologies and political regimes, that of Nazism and Communism. ${ }^{12}$

The problem with this kind of militant anti-communism is that it displays Jacobin tendencies that may be characteristic of many contemporary political movements on the Right, but are far removed from the thinking of those Central European dissidents who prevailed in 1989 (their anti-communism was anything but militant!). In fact, it is worth remembering that the Nazis were militant anti-communists, who also saw the French Revolution as anticipating the Bolshevik revolutions. Theirs was a 'conservative revolution' openly directed against the universal liberal values of the French Revolution. Militant anti-communism can be thus brought close to Goebbels who commented after the Nazi takeover in 1933: "With a stroke we have now obliterated 1789 from the history books." ${ }^{13}$ Clearly, the reluctant revolutionaries of 1989 were conservative in radically different ways, not least because they actually endorsed the enlightened values (partly) inherited from the French Revolution, while they remained committed to the rejection of violence in political struggle.

\section{Strange Revolutions/Strange Revolutionaries ${ }^{14}$}

The revolutions of 1989 do not fit easily into any preconceived notion of revolutionary change in Europe. These were self-limiting revolutions in which there was very little, or no violence; no radical break with the past; and very 
little or no revenge towards those who were responsible for the injustices of the old regime. In direct opposition to the revolutionary regime change orchestrated by the communists after the Second World War, the revolutions of 1989 were marked by constraint, not radicalism. They were, as Gale Stokes astutely observed, "revolutionary in the negative sense that they interred any realistic hope that the teleological experiment in the use of human reason to transform society in its entirety might succeed."15 In this way, they undermined the credibility of the revolutionary tradition usually traced back to the French Revolution, which was driven by the belief that radically new ideas would give rise to radically improved societies.

By any standards, the dissident intellectuals in Poland, Czechoslovakia and Hungary, who were catapulted into the position of leaders of these revolutions, were very unlikely revolutionaries. The likes of Václav Havel in Czechoslovakia, Adam Michnik in Poland and György Konrád in Hungary saw their struggle against the omnipotent communist state as an 'anti-political' struggle for authenticity, not a fight for political power. In line with this, they were reluctant to ally themselves with clearly defined ideological positions. Instead they appealed to a set of basic human values, assuming that a regime built on hypocrisy, greed and conformism could be defeated by truthfulness and a sense of basic human decency (hence Havel's notion of the "living in truth"). ${ }^{16}$

\section{9 and Theories of Modernisation}

These ideas may have been noble, but to many western observers they seemed antiquated and unsuitable as a basis for a coherent and clearly formulated political program. In line with this, dissident intellectuals and their ideas were not at the centre of scholarly attention before and (not even) after the collapse of communism. ${ }^{17}$ The disregard of western scholars towards intellectual developments amongst dissident intellectuals in Central and Eastern Europe was even easier to justify after the collapse of communism. There was not much to study, so the argument went, given the fact that the 1989 revolutions in Central and Eastern Europe did not bring about any new ideas. Jürgen Habermas, for example, identified as early as in 1990 "a peculiar characteristic of this revolution, namely its total lack of ideas that are either innovative or oriented towards the future." ${ }^{\prime 18}$ According to Claus Offe, this was also the reason why the prospects for the success of the postcommunist transition were rather slim. In a situation in which "the negative coalitions of dissidents and citizens' movements had no coherent political and economic project on their own, ${ }^{19}$ there was little hope for the countries of Central and Eastern Europe to master the multiple challenges of economic and political transformation. It was Offe who coined the memorable phrase of the "tunnel at the end of the light," which best captured the pessimistic predictions of many political theorists at the time..$^{20}$

We know now that most of those gloomy predictions did not materialise. The countries of Central Europe did not relapse to old, or new forms of despotism. It is worth remembering, however, that immediately after 1989 it would have been prudent to expect that the revolutions would turn nasty, and that people would end up supporting some kind of authoritarian regimes. The challenges ahead were indeed formidable, and it was by no means inevitable, for example, that the eruption of violence fuelled by extreme nationalism was limited to the Balkans. Yet, no similar developments took place in the countries of Central Europe. This is not to suggest that this process is irreversible, or that there are no challenges ahead-far from it. But I think that it is fair to say that despite many difficulties and significant current challenges, all the countries of Central Europe have developed remarkably stable political regimes, in which "liberal democracy is the only game in town." ${ }^{21}$

Historically speaking the failure of the revolutions would not have been unusual-it is their success that is remarkable and calls for explanation. As Hannah Arendt noted "it is perfectly true and a sad fact indeed, that most so-called revolutions, far from achieving constitutio libertatis, have not even been able to produce constitutional guarantees of civil rights and liberties, the blessings of 'limited government.'"22 Contrary to Offe's assumptions, I will argue (relying on Arendt and Burke) that the key to understanding the success of the 1989 Revolutions in Central Europe was their lack of radically new ideas. It was precisely because these revolutions were unoriginal and backward-looking that they were also largely successful. ${ }^{23}$

But before discussing 1989 as self-limiting conservative revolutions, it is useful to recall some crucial arguments of the theories of modernisation. Possibly the most plausible explanation for the revolutions of 1989 was to see them 
as 'catching up revolutions', revolutions which simply allowed the societies behind the former iron curtain to catch up with the rest of Europe in its neverending march towards modernity.

This interpretation had the great advantage of assimilating the experience of 1989 into the existing narratives of European history based on theories of modernisation. Although most observers rejected Fukuyama's claim about the end of history as far too simplistic, they were less disinclined to see 1989 as the culmination of those historic processes that were triggered originally in 1789. While the French Revolution marks the birth of modernity, 1989 brings Europe to maturity. In this account, the path of European civilisation towards ever-greater progress was merely interrupted by the tragic accidents of Nazism and communism. Typical is the assessment by Francois Furet, who believed that the revolutions of 1989 imbued

the famous principles of 1789 with a certain freshness and with renewed universality. As we begin to close the long and tragic digression that was the Communist illusion, we find ourselves more than ever confronted by the great dilemmas of democracy as they appeared at the end of the 18th century, expressed by ideas and by the course of the French Revolution. ${ }^{24}$

Furet's view is not without justification and it resonates with the views of some of the actors of the revolutions in 1989. György Konrád, for example, noted that their timing was "an edifying coincidence, one might say: an homage, at a remove of two hundred years, to the revolution that first proclaimed the civil rights of the individual." ${ }^{25}$ In fact, the most popular slogan of these revolutions, "the return to Europe," could be seen as the invocation of those principles that are usually associated with the heritage of the French Revolution: the ideals of freedom, equality and solidarity. ${ }^{26}$

Yet, the reliance on the theories of modernisation and the French Revolution as the exclusive paradigm of radical political change obscures some unique features of the revolutions of 1989. These theories focus on abstract historic forces and are hence ill equipped to deal with the impact of those imponderable factors that make societal change such a fascinating (and unpredictable) subject of inquiry: the role of personalities and their ideas; the role of cultural and political identities and the like. More generally, the theories of modernisation have little to add to our understanding of possibilities to challenge repressive political structures from within. It is telling that while most of those observers who were indebted to the modernisation theories failed to predict the collapse of communism, in hindsight the theory gives the most plausible explanation for the reasons of the 'inevitability' of this collapse. $^{27}$

Moreover, 1989 invalidated (or at least thoroughly discredited) one of the defining principles of 1789; the principle extolled by revolutionary leaders and thinkers from Robespierre through Lenin to Žižek, that a radical societal change is only possible as a result of a violent struggle..$^{28}$ The reluctant revolutionaries in Central Europe refused to accept that revolutionary violence should be used (and justified) as a liberating force. They rejected "the Jacobin orientations and program" based on "the belief in the possibility of transforming society through totalistic political action." In this way, the 1989 revolutions in Central Europe could be seen as undermining the credibility of that component of contemporary political discourse which S.N. Eisenstadt calls the "Jacobin dimension of modernity." 29

One of the obvious possible conclusions to draw from the limitations of modernisation theories in relation to the collapse of communism is to construe the 1989 revolutions as 'post-modern'. "Modernity's failure," in this view, ushered into "post-modernity's predicament." 30 "Postcommunism is postmodern," avers Richard Sakwa, "in the paradoxical sense that it returns to premodern traditions truncated by the triumph of modernity from the late eighteenth century." 31

The anti-communist revolutions of 1989-91 transcended the logic of modern vanguardist revolutions by espousing specific rather than universal goals, by transcending sectarian agendas with national ones, and by rejecting rather than innovating.... [T]hese were 'anti-revolutions,' repudiating the dynamic of revolution and counter-revolution in their entirety. In short, post-communism is post-revolutionism. ${ }^{32}$

In a similar vein, Boris Kapustin critiques the reductionism of modernisation theories for their tendency to assume that there is "an uncompromising opposition between 'tradition,' or better, 'traditionalism,' and 'modernity.'" 33 However, the attempts to replace modernisation theories with suitably adjusted theories of postmodernity are themselves not without limitations. Ironically, 
these theories still rely (if only implicitly) on the crude temporal logic that divides history into pre-modern, modern and post-modern times. As Johann P. Arnason reminds us, "visions of an existing or emerging postmodernity are always based on oversimplified images of modernity." ${ }^{\prime \prime 4}$ Hence the terms borrowed from post-modern discourse tend to obscure rather than clarify the political developments in the countries of the former Eastern bloc. ${ }^{35}$ At any rate, the talk about 'post-communism-as-postmodernity', or 'post-communism as post-revolutionism', adds little to our understanding of its problems (let alone helping the actors to deal with them).

\section{9 as Self-limiting Conservative Revolutions}

Rejecting various 'postist' labels and their pretensions, ${ }^{36}$ I want to suggest a simpler conceptual framework that should allow us to evaluate the meaning and significance of the 1989 revolutions without falling into the pitfalls of modernisation theories. Ironically, the term that would possibly better describe the events of 1989 is revolution in its original meaning as a return to an earlier state of affairs. This is the kind of revolutionary change defended by the critics of the French Revolution, such as Edmund Burke. Burke's famous rebuttal of the ideologically inspired violent excesses of the French Revolution strongly resonates with the key insights of dissident intellectuals in Central Europe: the concept of a self-limiting revolution, the idea of a 'return to normality' and the ideals of an ethical civil society and 'anti-politics'.

One does not need to adopt a postmodern idiom to argue (as Kapustin did) that it is unhelpful to postulate an unbridgeable gap between the political program of modernity and tradition. As David Gress demonstrated in a recen historic survey, the emergence of modernity and the concomitant rise of the West should not be seen as marking a radical break in human history (which can be conveniently dated with the French Revolution), but rather a result of long-lasting historic developments that should be traced back to its Greek, Latin and Christian origins. Gress challenges the myth of a sudden appearance of freedom in the western world and guards against the influence of the philosophical program of radical enlightenment (Rousseau). According to Gress, the political, social and economic phenomenon of modern liberty was made possible by the synthesis of the heritage of the Old West with the political values that came to be equated with the New West. ${ }^{37}$ This is clearly in line with the kind of thinking represented by Edmund Burke (and later Alexis de Tocqueville), but also of the dissident intellectuals in Central Europe

Ever since Burke's publication of the Reflections on the Revolution in France, ${ }^{38}$ the proponents of such revolutionary changes that aimed at delivering (instantly) both liberty and equality had to deal with one of the fundamental dilemmas of liberal democracy: the fact that democracy can destroy liberty. Thinkers as different as Alexis de Tocqueville, John Stuart Mill, Lord Acton, Hannah Arendt, and more recently Fareed Zakaria, ${ }^{39}$ from their different vantage points, warned against the danger of substituting the rule of mob for the rule of law: this was the problem of 'the tyranny of the majority'.

As Burke argued in his response to the French Revolution, unregulated liberty can lead to anarchy, in which everyone would lose out:

When I see the spirit of liberty in action, I see a strong principle at work and this, for a while, is all I can possibly know of it. [. . .] I should therefore suspend my congratulations on the new liberty of France, until I was informed how it had been combined with government; with public force; with the discipline and the obedience of armies; with the collection of an effective and well-distributed revenue; with morality and religion; with the solidity of property; with peace and order: with civil and social manners. [. . .]

The effect of liberty to individuals is, that they may do what they please: We ought to see what it will please them to do before we risque congratulations, which may be soon turned into complaints. ${ }^{40}$

Burke's reluctance to congratulate the French people on the attainment of liberty was vindicated once the revolution descended into a more violent phase The guillotine and the reign of terror under Robespierre, in Burke's view, were not just an aberration marking the betrayal of the initial ideals of the revolution, but a direct consequence of attempts at the implementation of those very same radical ideas. This is not to say that the descent to anarchy and the concomitant increase in political violence were inevitable, but rather that certain radical ideals can pave ground for these developments. This lesson was well understood by the dissident leaders in Central Europe who 
were vehemently opposed to the use of violence. Consider Michnik's comments about the virtues of democracy:

Democracy is not identical to freedom. Democracy is freedom written into the rule of law. Freedom in itself, without the limits imposed on it by law and tradition, is a road to anarchy and chaos—-where the right of the strongest rules. $^{41}$

Michnik's view echoes Burke, and is representative of the conscious effort of the reluctant revolutionaries to lay the ground for liberty under the rule of law.

\section{An Alternative Paradigm of Revolutionary Change: 1688 and} 1776 not 1789

In fact, even Burke himself can be seen as a defender of the ideals of liberty (if not equality), and a certain kind of revolutionary change, which he saw best embodied in the Glorious Revolution in Britain of 1688. As the full title of Burke's seminal work indicates, there was another dimension to his critic of the French Revolution often neglected in the discussions about modern revolutions, which was his concern with the protection of the legacies of revolution in Britain. ${ }^{42}$ Hence, Burke's key insights can also help in understanding the unique nature of 1989 by providing alternative points of reference, such as the Glorious Revolution of 1688 and the American Revolution of 1776. Burke's account of the revolution of 1688 that focuses on the attempt to preserve "antient indisputable laws and liberties," ${ }^{\prime 43}$ can be related to the notion of a "return to normality" in the countries of Central Europe. When Czechs, Poles, Slovaks and Hungarians shed their oppressive regimes, they believed (rightly or wrongly) that they were simply reclaiming their ancient liberties.

Hence, it was crucially important for the success of the 1989 revolutions in Central Europe that the universal liberal ideals were 'translated' into domestic nationalist discourses at the theoretical level, ${ }^{44}$ and into national constitutions and the emerging legal orders at the practical level. In this context, it is telling that the first president of the Hungarian constitutional court, László Sólyom, was able to justify a number of controversial decisions by referring to the existing "invisible constitution," as well as "the history of constitutional democracies," or "a common constitutional law of Europe." ${ }^{45}$ Václav Havel was also well aware of the challenge of embedding liberal principles within the national context. As he argued in an interview with Adam Michnik for the Polish newspaper Gazeta Wyborcza, universal liberal principles could not be a sufficient reason for the foundation of an independent state.

[Why] could we not become the seventeenth state of the Federal Republic of Germany, why have an independent state because of something which is a universal programme? I think it is necessary to seek other dimensions of Czech political traditions and Czech statehood. Something, to my mind, that has occurred repeatedly in Czech political life from time immemorial is a sense of a broader responsibility. [. . .] This sense of responsibility and the feeling that the Czech concern is a human concern (věc česká je věc lidská) can be found in St Wenceslas, Charles IV, George of Poděbrady, Comenius, Masaryk, Patočka. I think that this political line should become a part of the foundations of the new Czech state and even a warrant of its prospects. ${ }^{46}$

This combination of universalist and particularist agendas makes 1989 look more like the American struggle for independence-at least when one accepts Burke's interpretation of these events. In his view, the American colonists did not fight in the name of some abstract principles such as the Rights of Men but merely sought to "reclaim" their "Rights of Englishmen." "The feelings of the Colonies were formerly the feelings of Great Britain," argued Burke. ${ }^{47}$ Freedom was the most precious inheritance that the Americans gained from Britain:

We cannot, I fear, falsify the pedigree of this fierce people, and persuade them that they are not sprung from a nation, in whose veins the blood of freedom circulates. The language in which they would hear you tell them this tale, would detect the imposition; your speech would betray you. An Englishman is the unfittest person on earth to argue another Englishman into slavery. ${ }^{48}$

To do justice to Burke, it is important to acknowledge other differences between the French and the American Revolutions, which make the latter look more like the 1989 revolutions in Central Europe. Whatever is suggested in Thomas Jefferson's ambitious rhetoric in the Declaration of Independence, the goals of the American Revolution were always more moderate than the goals of the 
French Revolution. They were tempered by the concern of its leaders to avoid a descent into anarchy; to ensure stability and order in the new republic. As Irving Kristol observed (relying largely on Arendt's interpretation), "all revolutions unleash tides of passion, and the American Revolution was no exception. But it was exceptional in the degree to which it was able to subordinate these passions to serious and nuanced thinking about fundamental problems of political philosophy." ${ }^{\prime 4}$ This is the reason why Burke was able to endorse the American Revolution and oppose the French one later without being inconsistent. $^{50}$

For similar reasons, both a Burkean and an Arendtian position towards the American Revolution would allow for the endorsement of the revolutions in 1989. Michnik lends support to this interpretation in the Polish context, "Solidarity has never had a vision of an ideal society. It wants to live and let live. Its ideals are closer to the American Revolution than to the French." ${ }^{151}$ Yet, not many observers have paid attention to the similarities between the American Revolution of 1776 and the 1989 revolutions in Central Europe..$^{52}$ This may simply be one of the consequences of the long lasting infatuation of Western intellectuals with the French Revolution at the expense of its American predecessor. As Arendt noted,

It was the French and not the American Revolution that set the world on fire, and it was consequently from the course of the French Revolution, and not from the course of events in America or from the acts of the Founding Fathers, that our present use of the word 'revolution' received its connotations and overtones everywhere... The sad truth of the matter is that the French Revolution, which ended in disaster, has made world history, while the American Revolution, so triumphantly successful, has remained an event of little more than local importance. ${ }^{53}$

However, if we accept the 'Burkean' view of the 1989 revolutions as marking the end of the modern revolutionary tradition in Europe (derived from 1789), then the order of importance of the two revolutions, which Arendt bemoans, could be turned around. This is not to deny the limitations of the American paradigm of revolutionary change. Arendt was well aware of the difficulties in sustaining the noble values of the revolution, such as "public freedom, public happiness, public spirit," ${ }^{\prime 54}$ within everyday political practice once the revolution had been completed. The greatest challenge was how to keep alive the revolutionary spirit without suffering the consequences of revolutionary instability. Yet, according to Arendt, the American Revolution was more successful than its French counterpart in opening up new opportunities for citizens to become actively involved in politics as equals under the rule of law, because it managed to keep the balance between two conflicting elements: "the concern with stability and the spirit of the new. ${ }^{\prime 55}$ By focusing on political liberty rather than the issues of social equality, the American Revolution created public space for authentic political engagement. As Winfried Thaa forcefully demonstrated, the revolutions of 1989 can be seen as late vindications of Arendt's attempt to challenge the dominant concept of revolution in Europe with a "concept of revolution that does not seek the radical overthrow of the societal order, but rather, orientated on the American model, aims primarily at a renewal of the political space." ${ }^{56}$

Another aspect of the French Revolution, which was not echoed in 1989, was its adverse relation to religion. In fact, the hostility of the French enlightenment to religion, which Burke abhorred, can be contrasted with the importance of religious sentiments that fed into the revolutions of 1989. This also brings it closer to the American model that was "based on a political ideology transformed from a religious experience but maintaining its religious orientations." $^{157}$

\section{Spiritual Grounding of Liberal Democracy}

The most obvious example to illustrate this is, of course, Poland, where the role of the Catholic Church was not just contingent on the fact that it was the only institution that was relatively independent of the state (though this was undoubtedly an important factor too). There were also some profound philosophical reasons why the fight for liberty was seen in alliance with the fight for authentic religious faith. As the prominent Polish historian of Solidarity, Jan Józef Lipski clearly demonstrated, the movement was strongly influenced by a Christian ethos, which even a large majority of the non-religious members adopted as their own. This attitude was described by Jacek Kuroń in an essay with a revealing title: "A Christian Without God." 58

In Slovakia too, the 'Velvet Revolution' in 1989 was anticipated by large religious demonstrations in the summer of 1988, which had both openly politi-

374 - Stefan Auer 
cal as well as spiritual dimensions. Even in the Czech Republic, which is characterised by a thoroughly secular society, the defence of human rights was voiced in almost religious language. Consider Patočka's statement about the importance of human rights, which was published in a key document of Charter 77:

No society, no matter how well-equipped it may be technologically, can function without a moral foundation, without convictions that do not depend on convenience, circumstances, or expected advantage.... The idea of human rights is nothing other than the conviction that even states, even society as a whole, are subject to the sovereignty of moral sentiment: that they recognise something unconditional that is higher than they are, something that is binding even on them, sacred, inviolable ....$^{59}$

So, even Patočka, while remaining truthful to phenomenology and its antifoundationalist philosophical position, sought to ground the idea of human rights in "something unconditional." Following in his steps, Havel repeatedly stressed the importance of morality in politics; he talked about higher responsibility that he sought to justify with a reference to some higher entity: whether it be God, "the chain of being," "the voice of being," ${ }^{60}$ or any other metaphysical concept. ${ }^{61}$ While these philosophical positions may not warrant Derrida's reading of Patočka as "a fundamentally Christian thinker," alone Žižek's attack on Havel for his alleged "religious fundamentalism," it is clear that both Patočka and Havel were not dogmatically opposed to Christianity and recognised it as an in important (though not the only) resource for moral deliberations. Havel also repeatedly raised concerns about the destructive potential of the more ambitious and radical aspects of enlightenment, which gave rise to ideological frameworks, or in Burke's terminology "abstract designs." ${ }^{64}$

At any rate, both revolutions, the one in 1776 as well as the one in 1989, can be described as self-limiting revolutions. The idea of a self-limiting revolution emerged partly as a pragmatic response to a new geopolitical situation in Central and Eastern Europe. After a series of unsuccessful revolts against the Soviet style authoritarian communist regimes (in 1953 in Germany, 1956 in Hungary and Poland, and 1968 in Czechoslovakia), it became clear that no significant changes of the political system within the countries of Central
Europe were possible as long as the Soviet Union was determined to maintain its control over its satellite states. Yet, the actions of the reluctant revolutionaries in Central Europe were guided not only by these pragmatic considerations. Equally, or even more important, was their conviction that they had to exercise constraint in their own political struggle in order to prevent "the very negative experiences of all unlimited social revolutions of the Jacobin-Bolshevik type." ${ }^{\prime 65}$ They were also convinced that the "post-totalitarian' communist regimes could have been challenged from within by peaceful means, if only enough people were determined to defy it. This was the reasoning behind Havel's seminal essay "The Power of the Powerless," in which he rejected the use of violence inspired by dogmatic ideologies:

'dissidents' tend to be sceptical about political thought based on the faith that profound social changes can only be achieved by bringing about (regardless of the method) changes in the system or in the government, and the belief that such changes-because they are considered 'fundamental'-justify the sacrifice of 'less fundamental' things, in other words human lives. Respect for a theoretical concept here outweighs respect for human life. Yet this is precisely what threatens to enslave humanity all over again. ${ }^{66}$

Michnik was even more direct in rejecting the ideal of revolutionary violence associated with the French Revolution: "to believe in overthrowing the dictatorship of the party by revolution is both unrealistic and dangerous," he argued, because "those who use force to storm present-day Bastilles are likely to build bigger and worse Bastilles." ${ }^{\prime 67}$

Consequently, the opposition leaders were willing to constrain themselves in their exercise of power even after the actual collapse of communism. They made considerable efforts to maintain "the fiction of legal continuity with a past without legality." ${ }^{\prime \prime 8}$ As Arato commented, this is one of the remarkable legacies of 1989. "It is the great contribution of the Central and East European struggle for legality in the midst of radical transformation that, even without inherited republican institutions, the new can be built without total rupture with the past." ${ }^{\prime 69}$ The anti-communist revolutionaries were prepared to make deals with their former communist foes, because they feared that the alternative would have brought about a descent to chaos and anarchy. These actors "were trying at all times to promote a revolution without a revolution. ${ }^{\text {"70 }}$

376 - Stefan Auer 
Another distinguishing feature of the self-limiting 1989 revolutions in Central Europe was their negotiated character. The negotiations allowed for a political transition that was radical in its speed but very moderate in its means. One of the crucial factors in this was the restraint shown by the leaders of the democratic opposition. Adam Michnik defended his conciliatory stance towards the communists in the round table discussions in summer 1989 as follows: "The path of negotiations brings many disappointments, bitterness, and a sense of injustice and unfulfillment. But it does not bring victims. Disappointed are those who are, after all, alive." ${ }^{\prime 71}$

Moreover, the opposition leaders did not see themselves as the only possible representatives of "a monolithic people in revolt against its masters" but, rather, sought to represent "the multiplicity and diversity of all citizens." ${ }^{\prime 72}$ This point could be nicely illustrated with the analysis of the strategies used by the Czechoslovak dissident movement Charter 77. As its founding members such as Václav Havel and Jan Patočka repeatedly stressed, the main purpose of the movement was to engage the communist rulers in an open-ended dialogue with all sectors of society. This ideal informed also the working methods of the leading citizen movement in the revolution of 1989, the socalled Civic Forum. The Czech historian Jiři Suk may have gone too far by suggesting that one could usefully relate this instigation to dialogue to the Habermasian concept of a "communicative ethics,"73 but there can be little doubt that they constituted an attempt to reclaim the public sphere as a space for genuine political engagement. In this sense, one can also talk about "a return to normality," ${ }^{\prime 74}$ in which the lives of citizens were no longer to be determined by the bureaucratic monopoly of the communist party, but rather by an open-ended contest between different societal actors.

\section{'Return to Normality'}

The notion of a 'return to normality' may have been very ambiguous, ${ }^{75}$ but it found resonance with a vast majority of the people. Many Poles, Czechs, Slovaks and Hungarians simply desired to restore a sense of normality after the 'foolish experiment' of communism. The fact that this 'normality' was equated with securing life-styles that were thought characteristic of the wellestablished democracies in the West, and was hence quite removed from any present or past experiences of the peoples in Central Europe, did not prevent them from seeing it as their natural destiny. It was their return to a past that (may have) never existed (or a past they could have had but for communism). As the Polish sociologist Jerzy Jedlicki wryly remarked, Poland has always been returning to Europe, although it has actually never been there. ${ }^{76}$ Yet, it is precisely thanks to this perception, that it was possible for the Poles, Czechs, Slovaks and Hungarians to see their fight for liberty as being in line with the best aspects of their own national traditions..$^{77}$ In this way, the notion of a return to normality linked the project of postcommunist transition, which was oriented towards a liberal-democratic future, with the pre-communist past.

However, not only the pre-communist past served as a point of reference for the evaluation of liberal values. The new leaders also sought to rally people in support of liberal values by recalling their failed revolts against communism. This return to the best aspects of dissident past(s) was obviously in conflict with the second aspect of self-limiting conservative revolutions, the effort to maintain the fiction of legal continuity with the illegal and illegitimate communist regime. Clearly, these were contradictory impulses: one could not 'preserve' pasts, which were so radically different and even mutually exclusive. Yet, it was done even when it led to grotesque occurrences. It suffices to recall that Václav Havel, who as a leader of Charter 77 was thoroughly despised by the communists, was voted into the presidency of Czechoslovakia in December 1989 by the national assembly clearly dominated by the communists.

In fact, there is a further irony that makes the 1989 revolutions conservative in the Burkean sense. Even though the 1989 revolutions shared a number of goals with 1789, which Burke opposed in his own times, many of the radical ideas from more than 200 hundred years ago seem less radical today. For example, Burke was not unusual in his own time in opposing democratic ideals and the modern concept of citizenship; ${ }^{78}$ these enlightened concepts were generally seen as too radical, and dangerous for liberty. However, two hundred years after the French Revolution the ideals of the French revolutionaries themselves became a part of a European, or Western tradition, ${ }^{79}$ and most people today would not think of democracy and liberty as inherently incompatible.

Similarly, the ideal of universal human rights, which was vehemently opposed by Burke as far too radical and dangerous, has become a powerful source of 
inspiration for people with vastly different backgrounds; the discourse of human rights today cuts across all ideological boundaries. It is worth remembering, however, that this is a result of a relatively recent development (from Helsinki 1975 to Charter 1977 to the notion of 'human rights wars' in Kosovo and Iraq), in which Central and East European intellectuals played a crucial role. Even Arendt subscribed to Burke's views on human rights as late as in the 1960s. As she put it, "the perplexities of the Rights of Man are manifold, and Burke's famous argument against them is neither obsolete nor 'reactionary.'"'80 Like Burke, Arendt believed that the ideal of universal human rights is far too ambitious to be useful in practical politics. ${ }^{81}$ Like Burke, she was convinced that people only acquire rights through belonging to a particular political community, one which is capable and willing of enforcing them: "We are not born equal; we become equal as members of a group on the strength of our decision to guarantee ourselves mutually equal rights." ${ }^{82}$

\section{Anti-Politics and Civil Society}

Due to the recent popularity of the concept of civil society, which transcends ideological boundaries, it may be easily forgotten that the concept was originally based on a rather conservative ideal-the conviction that free societies rely on private virtues. Good character and virtue, according to Burke, cannot be developed as a result of an abstract ideal of humanity. They can only be fostered within a relatively small community of citizens here and now; within the 'little platoons', in which everyone knows their place (moving in expanding concentric circles from your family to your neighbourhood, from your neighbourhood to your city, from your city to your nation and the wider world). One does not become virtuous simply by understanding and accepting the wisdom of Rousseau's 'General Will', or the Kantian 'categorical imperative'. Similarly, for Hannah Arendt, there is not much use in invoking the noble principles of liberty, unless the kind of political space is (re-)created in society, in which authentic actions of independent citizens can take place. Burke's own personal example showed that this is not to say that one should limit one's moral concerns to one's own small community. But the starting point must be your concern with the individuals here and now. As Burke put it:

I have no great opinion of that sublime abstract, metaphysic reversionary, contingent humanity, which in cold blood can subject the present time and those whom we daily see and converse with to immediate calamities in favour

of the future and uncertain benefit of persons who only exist in idea. ${ }^{83}$

Once again, this kind of reasoning resonates with the convictions of dissident intellectuals (for example, Havel, Michnik, Konrád), who strongly believed that only through changing the 'hearts and minds' of individual members of society could communism be defeated, and later the process of postcommunist transition succeed. This is why Havel repeatedly stressed that one must turn away from "abstract political visions of the future and toward concrete human beings and ways of defending them effectively in the here and now. ${ }^{84}$ Hence, any genuine political engagement had to be a result of taking concrete responsibility. This was the ideal of an ethical civil society.

In its initial form, the concept of civil society was not meant to be revolutionary; civil society was not seen as directed against the state, but was supposed to complement it. That was the vision inherited "from Locke, the Scottish Enlightenment, Burke, Hegel, and de Tocqueville." ${ }^{\prime 85}$ As one of the leading Hungarian intellectuals, G.M. Tamás, explained, the dissidents in Central Europe appropriated this concept creatively for their own purposes and turned it against the oppressive communist state. This antagonism between state and society is reminiscent more of Thomas Paine than Burke, and it is not surprising, hence, that the Central European concept of civil society had strong appeal to the left-wing intellectuals in the West. ${ }^{86}$ It was Paine who asserted in Common Sense that "society is in every state a blessing, but government, even in its best state, is but a necessary evil." ${ }^{17}$

The dissident's suspicion of the communist state and its official ideology, Marxism, found its expression in the idea of anti-politics. Anti-politics was directed not only against the state, but any institutionalised politics, and was hostile not only towards Marxism, but any (dogmatic) political ideology in general. However, it would be a crude misunderstanding to see the ideal of anti-politics as apolitical. On the contrary, by liberating individuals from the constraints of institutional politics and the schematic thinking imposed by abstract ideological frameworks, individuals were empowered to endow their actions with authentic meaning: in this sense personal became political. The ideal of anti-politics urged people to act "as if" they were free, ${ }^{88}$ and to assume

$380 \cdot$ Stefan Auer 
responsibility that comes with freedom. Hence, anti-politics was not a politics without principles, rather simply a "politics without cliché." 89

In fact, if there is one distinct contribution from the intellectuals from Central and Eastern Europe to political theory in general, it is to be found in their conviction that "the old categories of ideological contestation have become hopelessly clichéd: they refer only to themselves in tendentious circles of selfreferentiality." ${ }^{\prime 90}$ While many intellectuals in the West seem still indebted to these ideological frameworks (even when intent on overcoming them) ${ }_{1}^{91}$ most intellectuals in Central Europe abandoned them. However, even though this 'post-ideological' position rejects all great narratives it would be a mistake to label it as post-modern (especially if postmodernism implies moral relativism). As I have argued, it is much closer to the thinking of the likes of Burke, who identified the dangers of schematic ideological thinking well before it became one of the dominant features of modernity. Arendt shared this suspicion of ideologies, which have the tendency to neatly divide the political world into binary oppositions. This is reflected in her critique of conventional theories of revolution, which underpin the argument about the selflimiting conservative revolutions of 1989 advanced in this article. In her view "the very fact that these two elements [which were contained in the spirit of revolution], the concern with stability and the spirit of the new, have become opposites in political thought and terminology-the one being identified as conservatism and the other being claimed as the monopoly of progressive liberalism-must be recognized to be among the symptoms of our loss." ${ }^{\prime 92}$ Hence, following Arendt, the legacy of the revolutions of 1989 in Central Europe can be seen as an invitation to rethink the relationship between the ongoing concern with political stability and the desire for a radical renewal.

\section{Concluding Remarks}

The attempts of Central European dissidents to reclaim the sphere of politics as a place for human authenticity resulted in their rejection of ideologies. Leszek Kołakowski offered a witty justification of this approach in the late 1970s. He proposed the establishment of a Conservative-Liberal Socialist International, which was based on the assumption that the differences between the sensible parts of these ideologies were not insurmountable. Thus, their conflicting demands were not mutually exclusive. ${ }^{93}$ In line with this, the dissident intellectuals in Central Europe were able to follow radically conflicting ideals that led to the relative success of their self-limiting conservative revolutions in 1989.

The goals of these conservative revolutionaries were both modest and ambitious. They were modest, because they did not openly seek political power ambitious because they aimed at a redefinition of political space and activities within it. It may be questioned as to how successful these revolutions were in delivering those more ambitious goals. As Arendt reminds us, to sustain the spirit of the revolution after the event is very difficult, if not impossible. However, the attempts of the reluctant revolutionaries to reclaim the sphere of politics as a place for human authenticity must be seen, like democracy, as a part of an open-ended project-a normative ideal worth striving for, rather than something that can be achieved overnight (or in those 15 years that passed since the collapse of communism). The revolutions were successful to the extent that they created preconditions for liberty under the rule of law. The relative success of the conservative revolutions in Centra Europe could give some hope to those political theorists who, like S.N. Eisenstadt, believe that 'the paradoxes of democracy' do not need to (and should not) lead to its ultimate demise.

* Stefan Auer, Dublin European Institute, University College Dublin, Belfield, Dublin 4, Ireland.

\section{Notes}

I wish to thank András Bozóki, Christopher Finlay, Tom Garvin, Andreas Hess, Robert Horvath, Martin Krygier, Tim Mehigan, Suzanne Mulcahy, Tony Philips, Charles Sowerwine, Tobias Theiler and Ben Tonra for their support and constructive criticism of earlier versions of this paper. I also benefited from the facilities of the Contemporary Europe Research Centre in Melbourne in producing this paper.

2 Central Europe, for the purposes of this article, denotes the countries of the socalled Visegrad four: the Czech Republic, Slovakia (that is Czechoslovakia before 1993), Poland and Hungary.

3 Hannah Arendt, On Revolution, New York, The Viking Press, 1965

4 This is in marked contrast to those contemporary neo-conservatives in the United 
States who believe that there are virtually no limits to their ambitious project of radically remaking the existing world order. Their thinking displays more Jacobin rather than Burkean tendencies.

5 Conor Cruise O'Brien, The Great Melody: A Thematic Biography and Commented Anthology of Edmund Burke, Chicago, University of Chicago Press, 1992.

6 Martin Krygier, "Conservative-Liberal-Socialism Revisited," The Good Society, vol. 11 , no. 1,2002 , p. 8

7 While I do not seek to establish a causal relationship between Burke and the 1989 revolutions (Burke provides me simply with an interpretative vantage point), it is worth noting that Michnik admired Burke's work. In a February 1988 interview for the Times Literary Supplement Michnik bemoaned the fact that Burke's Reflections were banned in Poland and suggested that if he "was proficient in English [he] would translate this book and present Gorbachev and others with a complimentary copy-to teach them the philosophy of compromise." Adam Michnik, Letters from Freedom: Post-Cold War Realities and Perspectives, Berkeley, University of California Press, 1998, p. 111.

8 Krygier, “Conservative-Liberal-Socialism," p. 7.

9 As Darrin M. McMahon noted, towards the end of his life Burke increasingly adopted dogmatic views inspired by those French reactionaries, whose "modern politics of the Right was not conservative but revolutionary in its desire to remake the world in the image of a rigorous ideal." Darrin M. McMahon, "Edmund Burke and the Literary Cabal: A Tale of Two Enlightenments," in Reflections on the Revolution in France, ed. Frank M. Turner, New Haven and London, Yale University Press, 2003, p. 245. In contrast, earlier writings of Burke can be seen as anticipating the concerns of critical theory and postmodern philosophy. As Stephen K. White argued, “Burke's critique of modernity begins to exhibit some family resemblance to contemporary ones that have focused upon the costs of the modern imperatives of rationalization, especially the unlimited drive to mastery, both of the self and of the world around us." Stephen K. White, Edmund Burke: Modernity, Politics, and Aesthetics, Thousand Oaks, Calif., Sage, 1994, p. 84.

10 Conor Cruise O'Brien, "Introduction," in Edmund Burke, Reflections on the Revolution in France, Harmondsworth, Penguin, 1986, p. 51.

11 "Burke would have been likely to see in the principles of the Communist revolution the emergence in even purer form of all that he most detested in the contemporary revolution whose progress he watched with horror and fascination in France, and sought with eloquence and skill to check in England. The spirit of total, radical innovation; the overthrow of all prescriptive rights; the confiscation of property; destruction of the Church, the nobility, the family, tradition, veneration, the ancestors, the nation-this is the catalogue of all that Burke dreaded in his darkest moments, and every item in it he would have discovered in Marxism." Ibid., pp. 9-10.

12 Ernst Nolte, “Die unvollständige Revolution: Die Rehabilitierung des Bürgertum und der defensive Nationalismus," Frankfurter Allgemeine Zeitung, January 24, 1991 p. 27. I have no space to explore the controversy that Nolte's interpretative framework caused in Germany and beyond. Suffice to say that his thesis triggered the so-called "Historikerstreit," in which Nolte was accused of being apologetic of Nazi crimes by playing down their historic significance. It is interesting to note, however, that some aspects of his theory are today accepted within the mainstream. It is no longer taboo, for example, to compare Nazism and Communism, and to contextualise the rise of Nazism within the broader context of European history. See for example, Mark Mazower, Dark Continent: Europe's Twentieth Century London, Penguin, 1999. For a good summary of key Nolte's ideas and their evaluation see also François Furet, The Passing of an Illusion: The Idea of Communism in the Twentieth Century, trans. Deborah Furet, Chicago, Chicago University Press, 1999, pp. 518-9.

13 Stefan Steinberg, "Right-Wing Historian Ernst Nolte Receives the Konrad Adenauer Prize for Science," World Socialist Web Site, 17 August 2000.

14 The following section relies heavily on my article, "Das Erbe von 1989: die Revolutionen für Europa," Osteuropa, 54: 5-6, 2004.

15 Gale Stokes, Three Eras of Political Change in Eastern Europe, New York, Oxford, Oxford University Press, 1997, p. 163

16 Václav Havel, "The Power of the Powerless," in The Power of the Powerless: Citizen against the State in Central-Eastern, ed. John Keane, Armonk, N.Y., M.E. Sharpe, 1985

17 Winfried Thaa, Die Wiedergeburt des Politischen: Zivilgesellschaft und Legitimitätskonflik in den Revolutionen von 1989, Opladen, Leske + Budrich, 1996, p. 34. See also Jeffrey C. Isaac, "The Strange Silence of Political Theory," Political Theory, vol. 23, no. 4, 1995.

18 Jürgen Habermas, "What Does Socialism Mean Today? The Rectifying Revolution and the Need for New Thinking on the Left," New Left Review, 183, 1990, p. 5.

19 Claus Offe, Varieties of Transition: The East European and East German Experience, Cambridge, Massachusetts, The MIT Press, 1997, p. 43

20 Claus Offe, Der Tunnel am Ende des Lichts: Erkundungen der politischen Transformation im Neuen Osten, Frankfurt/Main, Campus Verlag, 1994.

21 Juan J. Linz and Alfred E. Stepan, Problems of Democratic Transition and Consolidation: Southern Europe, South America, and Post-Communist Europe, Baltimore, Johns Hopkins University Press, 1996, p. 5.

22 Arendt, On Revolution, p. 220, cf. 111. More recently, Andrew Arato has also argued

384 - Stefan Auer 
that "revolutions ... are rarely conducive to democracy." Andrew Arato, Civil Society, Constitution, and Legitimacy, Oxford, Rowman \& Littlefield, 2000, p. 80.

23 This is not to say that other aspects were not important. The international environment, for example, "has been exceptionally favourable to the democratic transition in Central Europe." Jacques Rupnik, "The Postcommunist Divide," Journal of Democracy, vol. 10, no. 1, 1999, p. 62

24 François Furet, “From 1789 to 1917 \& 1989," Encounter, 1990, p. 5.

25 György Konrád, The Melancholy of Rebirth: Essays from Post-Communist Central Europe, 1989-1994, San Diego, Harcourt Brace, 1995, p. 22.

26 Europe was for most people in Central Europe primarily a political concept synonymous with the West; that is with the traditions of liberal democracy. Already in November 1956, for example, when there was a popular uprising against the communist rule in Hungary, the director of the Hungarian News agency called for help against the Soviet invasion with the following words: "We are going to die for Hungary and for Europe" (my italics). Milan Kundera, "The Tragedy of Central Europe," New York Review of Books, 1984, 33

${ }^{27}$ For a persuasive critique of the theories of modernisation see Thaa, Die Wiedergeburt des Politischen; for a useful and comprehensive overview of the theories of collapse of communism see, for example, Leslie Holmes, Post-Communism: An Introduction, Cambridge, Polity Press, 1997. For arguments against historic determinism see, for example, Edgar Morin, "The Anti-Totalitarian Revolution," in Between Totalitarianism and Postmodernity, eds. Gillian Robinson Peter Beilharz, and John Rundell, Cambridge, Mass., The MIT Press, 1992, p. 93.

28 Most historians of the French Revolution differentiate between its different phases, and would hence challenge the notion that the rise of Robespierre and Jacobinism could be traced back to 1789, but for Burke there was no substantial difference between 1789 and 1793. For the view of revolutionary violence as "an authentic act of liberation" see Žižek's recent commentary on Lenin in Slavoj Žižek, Revolution at the Gates, London, Verso, 2002, especially pp. 259-61. For a persuasive critique of this argument see for example Jörg Lau, "Auf der Suche nach dem guten Terror: Über Slavoj Žižek," Merkur, vol. 57, no. 2, 2003, pp. 158-63.

29 S.N. Eisenstadt, Fundamentalism, Sectarianism, and Revolution: The Jacobin Dimension of Modernity, Cambridge, Cambridge University Press, 1999, p. 72.

30 Boris Kapustin, “Modernity's Failure/Post-Modernity's Predicament: The Case of Russia," Critical Horizons, vol. 4, no. 1, 2003. While Kapustin develops his argument with respect to Russia, some of his insights could be applied also to Central Europe.

31 Richard Sakwa, Postcommunism, Buckingham, Open University Press, 1999, p. 89

32 Ibid., pp. 90-91.
33 Kapustin "Modernity's Failure," p. 102

${ }^{34}$ Johann P. Arnason, "The Post-Mode and Its Pretensions," in Civilizations in Dispute, Leiden, Boston, Brill, 2003, p. 341

35 I do not find it helpful to describe, as Kapustin does, the failed economic reforms in Russia "the post-modernisation of the economy," and the failures of the current political system in Russia as "Communism's relapse into post-modernity." One does not need to accept that there was only one path open to Russia after the collapse of communism, to maintain that it is meaningful to talk about relative successes and failures of certain political and economic measures. The conceptual confusion is best encapsulated in the description of the current economic predicament as "the post-modern capitalistic re-feudalisation of Russia." Kapustin, “Modernity's Failure," pp. 127, 31, 29.

36 Arnason, "The Post-Mode and Its Pretensions," pp. 339-46.

37 David Gress, From Plato to Nato: The Idea of the West and Its Opponents, New York, Free Press, 1998

38 Edmund Burke and J.C.D. Clark, Reflections on the Revolution in France, Stanford, Calif., Stanford University Press, 2001.

39 Fareed Zakaria, The Future of Freedom: Illiberal Democracy at Home and Abroad, New York, W.W. Norton, 2003. For a useful overview of nineteenth century critical responses to the French Revolution see, for example, Timothy O'Hagan, "Liberal Critics of the French Revolution," in Revolution and Enlightenment in Europe, ed. Timothy O'Hagan, Aberdeen, Aberdeen University Press, 1991.

40 Edmund Burke and Conor Cruise O'Brien, Reflections on the Revolution in France, Harmondsworth, Penguin, 1986, pp. 89-91.

41 Michnik, Letters from Freedom, p. 320.

42 Reflections on the revolution in France, and on the proceedings in certain societies in London relative to that event in a letter intended to have been sent to a gentleman in Paris. As J.C.D. Clark argued, Burke "did not defend an old world against a new world; he defended his modern world (Whig, commercial, rational, patrician, Anglican) against assault by atavistic moral, intellectual and political vices." Burke and Clark, Reflections, p. 89. In line with this, a number of contemporary political theorists and historians seek to reclaim the heritage of Edmund Burke, and present him partly as a predecessor of liberalism. See, for example, Gress, From Plato to Nato; Lawrence E. Cahoone, Civil Society: The Conservative Meaning of Liberal Politics, Malden, Massachusetts, Blackwell, 2002, pp. 6, 119; Martin Greenberg, "Burke \& Political Liberty," New Criterion, vol. 20, no. 7, 2002

43 Burke and Clark, Reflections, p. 181.

4 See, in greater detail, Stefan Auer, Liberal Nationalism in Central Europe, London, Routledge, 2004

386 - Stefan Auer 
45 Kim Lane Scheppele, "The New Hungarian Constitutional Court," East European Constitutional Review, vol. 8, no. 4, 1999; László Sólyom and Georg Brunner, Constitutional Judiciary in a New Democracy: The Hungarian Constitutional Court, Ann Arbor, Mich., University of Michigan Press, 2000, p. 219.

46 Havel in Lidové noviny 11.9.92; cf. also Václav Havel, Letní prememítaní, Praha, Odeon, 1991, pp. 111-5.

47 Edmund Burke, "Speech on American Taxation, 19 April 1774," in The Writings and Speeches of Edmund Burke, ed. William B. Todd and Paul Langford, Oxford, Oxford University Press, 1981, p. 417.

48 Edmund Burke, "Speech on Conciliation with America, 22 March 1775," in On Empire, Liberty, and Reform: Speeches and Letters, ed. David Bromwich, New Haven, Yale University Press, 2000, p. 92.

49 Irving Kristol, "The American Revolution as a Successful Revolution," in America's Continuing Revolution, Doubleday, Garden City, New York, Anchor Press, 1976, p. 4. For a more recent formulation of this argument see for example Susan Dunn, Sister Revolutions: French Lightning, American Light, New York, Faber and Faber, 1999

50 According to Harvey C. Mansfield, Burke never systematically addressed this apparent paradox, though he touches on it in a letter to William Windham, written in 1797. See Edmund Burke and Harvey Claflin Mansfield, Selected Letters of Edmund Burke, Chicago, University of Chicago Press, 1984, p. 216.

${ }^{51}$ Cited in Barbara Falk, The Dilemmas of Dissidence in Eastern Europe, Budapest, CEU Press, 2003, p. 183.

52 "And what of 1776 and 1688 and 1640?" asked Krishan Kumar rhetorically. “The literature on 1989 is noticeably thin on references to these revolutions, by comparison with later ones." Krishan Kumar, 1989: Revolutionary Ideas and Ideals, Minneapolis, University of Minnesota Press, 2001, p. 119.

53 Arendt, On Revolution, 49

54 Ibid., p. 223.

55 Ibid., p. 225.

6 Thaa, Die Wiedergeburt des Politischen, p. 142

57 Shmuel Noah Eisenstadt, Paradoxes of Democracy: Fragility, Continuity, and Change, Washington, D.C., Woodrow Wilson Center Press, 1999, p. 58

58 Jan Józef Lipski, KOR: A History of the Workers' Defense Committee in Poland, 19761981, trans. Olga Amsterdamska and Gene M. Moore, Berkeley, University of California Press, 1985, p. 75. Consider also the work of Józef Tischner and Michnik's response to it. Adam Michnik and David Ost, The Church and the Left, Chicago, University of Chicago Press, 1993; Tischner, Etika Solidarity, Bratislava, Kalligram, 1998. More recently, a number of Polish intellectuals and politicians advocated that the new European constitution, proposed by the Convention on the Future of Europe, would refer to God in the preamble. According to Tadeusz Mazowiecki, Poland's first postcommunist Prime Minister, leaving God out of the constitution is like "someone cutting the Cathedral of Notre Dame out of a Paris album." Cited in Time, June 16, 2003, 161:24, [http://www.time.com/time/Europe/magazine] A similar argument was also advanced by the former Polish Foreing Minister, Bronisław Geremek: Consider that even Voltaire talked about "Christian Europe." Bronisław Geremek, "Europe: United or Divided? Enlargement and Future of the European Union" (paper presented at the Irish Central European Dialogues, Dublin, Royal Irish Academy, March 26, 2004).

59 Erazim Kohák, Jan Patočka: Philosophy and Selected Writings, Chicago, The University of Chicago Press, 1989, p. 341. For more background material on the Charter 77 and the original version of this document see Jan Patočka, "O provinnosti bránit se proti bezpráví," in Charta 77, ed. Vilém Prečan, Bratislava, Archa, 1990, pp. 31-33.

60 Václav Havel, Letters to Olga: June 1979-September 1982, New York, Knopf, 1988, pp. 352-5.

61 Cf. Burke's preoccupation with the importance of the awareness of "human finitude" and the role of the sublime in politics. See White, Edmund Burke.

62 Jacques Derrida, The Gift of Death, Religion and Postmodernism, Chicago, University of Chicago Press, 1995. For a convincing critique of Derrida's reading of Patočka see Edward F. Findlay, "Secrets of European Responsibility: Jacques Derrida on Responsibility in the Philosophy of Jan Patočka," Philosophy Today, vol. 46, no. 1, 2002

63 Slavoj Žižek, "Attempts to Escape the Logic of Capitalism," London Review of Books, 1999, 4.

64 Gress, From Plato to Nato, p. 489

65 Arato, Civil Society, p. 48.

66 Incidentally, it is worth noting that Havel allowed for the possibility that violence may be justifiable "as a necessary evil in extreme situations, when direct violence can only be met by violence and where remaining passive would in effect mean supporting violence: let us recall, for example, that the blindness of European pacifism was one of the factors that prepared the ground for the Second World War." Havel, "The Power of the Powerless," p. 71. In line with this, Havel was able to endorse, if not without qualification, the US led invasion of Iraq.

67 Michnik, Letters from Freedom, p. 106. Michnik made this argument firstly in Adam Michnik, Letters from Prison and Other Essays, Berkeley, University of California Press, 1985, pp. 86-7.

68 Arato, Civil Society, p. xiv. This approach found its legal expression in one of the key decisions of the newly established Hungarian constitutional court ('On

388 - Stefan Auer 
Retroactive Criminal Legislation,' 5 March 1992). It was justified thus: “The change of system has been carried out on the basis of legality.... The old law retains its validity. With respect to its validity, there is no distinction between 'pre-Constitution' and 'post-Constitution' law. The legitimacy of the different (political) systems during the past half century is irrelevant from this perspective; that is from the viewpoint of the constitutionality of laws, it does not comprise a meaningful category." Sólyom and Brunner, Constitutional Judiciary in a New Democracy, p. 220.

69 Arato, Civil Society, p. xiv.

$70 \quad$ Ibid., p. 15.

${ }^{71}$ Elzbieta Matynia, "Furnishing Democracy at the End of the Century: The Polish Round Table and Others," East European Politics and Societies, vol. 15, no. 2, 2001, p. 457.

72 Ulrich Preuss cited in William E. Scheuerman, "The Rule of Law at Century's End," Political Theory, vol. 25, no. 5, 1997.

73 Jiří Suk, Labyrintem revoluce, Prague, Prostor, 2003, pp. 72-73.

74 Tadeusz Mazowiecki was hence able to proclaim in August 1989: “One has return to Poland the mechanisms of normal political life. The transition is difficult, but it does not have to cause shaking. On the contrary, it will be a path to normalcy." Tadeusz Mazowiecki, "A Solidarity Government Takes Power," in From Stalinism to Pluralism: A Documentary History of Eastern Europe since 1945, ed. Gale Stokes, Oxford, Oxford University Press, 1996, p. 229.

75 Holmes, Post-Communism: An Introduction, pp. 335-6.

76 Jerzy Jedlicki, "The Revolution of 1989: The Unbearable Burden of History," Problems of Communism, 1990, pp. 39-45.

77 Auer, Liberal Nationalism in Central Europe.

78 This is the main reason why "Burke's remains an incomplete vision of politics." For an insightful discussion of Burke's shortcomings with respect to the issues of equality in a politically liberal society see, for example, Frank M. Turner, "Edmund Burke: The Political Actor Thinking," in Reflections on the Revolution in France, ed. Frank M. Turner, New Haven and London, Yale University Press, 2003, pp. xxxix-xli.

79 Cahoone, Civil Society, p. 119

80 Arendt, On Revolution, p. 104.

${ }^{81}$ "No statesman, no political figure of any importance could possibly take them seriously; and none of the liberal or radical parties in Europe thought it necessary to incorporate into their program a new declaration on human rights." Hannah Arendt, The Origins of Totalitarianism, London, Allen \& Unwin, 1966, p. 292.

82 Ibid., p. 301.

83 Burke in O'Brien, "Introduction," p. 23.
84 Havel, "The Power of the Powerless," p. 71.

85 G.M. Tamás, "The Legacy of Dissent," in The Revolutions of 1989, ed. Vladimir Tismaneanu, London, Routledge, 1999, p. 188

86 David Ost, for example, in his influential study of Solidarity insists on labelling this movement as a leftist group, or, taking into consideration its peculiar relationship towards ideology, "a postmodern left." David Ost, Solidarity and the Politics of Anti-Politics, Philadelphia, Temple University Press, 1990, p. 16.

87 Eric Foner, "Introduction," in Thomas Paine: Rights of Man, Harmondsworth, Penguin, 1985, p. 11.

88 See H. Gordon Skilling, Charter 77 and Human Rights in Czechoslovakia, London, Scribner, 1981, p. 211, and Stokes, Three Eras of Political Change in Eastern Europe, p. 170.

89 Jean Bethke Elshtain, "Politics without Cliché," in Real Politics: At the Center of Everyday Life, Baltimore, Md., Johns Hopkins University Press, 1997, pp. 3-11.

90 Ibid., p. 4.

91 Consider, for example, Sakwa's discussion of the aims of the 1989 revolutions: "These revolutions were directed not to fulfil the Marxist promise but to transcend it." Sakwa, Postcommunism, p. 91. In a similar vein, Arato characterised the concept of civil society, which emerged in Central Europe, as "post-Marxist." Arato, Civil Society, p. 43. Finally, when John Keane interviewed Michnik, shortly before the collapse of communism, he was perplexed by the fact that Michnik believes in the importance of compromise, which "has its roots in the early conservative tradition." Michnik, in response, was at ease transcending ideological boundaries and looking for inspiration by thinkers as different as Hannah Arendt, Edmund Burke, George Orwell, and Albert Camus. He pointed out that "the philosophy of compromise is a philosophy which recognizes quandaries. The philosophy of radicalism, revolution, demagogy, and violence, by contrast, takes an easier path, although $[\ldots]$ it produces the guillotine and not democracy. From its inception the left failed to recognize this. It lacked an understanding of the conservative perspective." Michnik, Letters from Freedom, p. 110.

92 Arendt, On Revolution, p. 225.

93 Leszek Kołakowski, "How to Be a Conservative-Liberal Socialist," Encounter, vol. 51, no. 4, 1978. For more recent restatements of Kołakowski's provocative argument see Ferenc Fehér, "1989 and the Deconstruction of Political Monism," Thesis Eleven, 42, 1995, 96, 100-4 and Krygier, "Conservative-Liberal-Socialism." 